\title{
A cytogenetic and haematological investigation of oil exposed workers in a Norwegian cable manufacturing company
}

\author{
K SKYBERG,' INGER-LISE HANSTEEN, ${ }^{2} \varnothing$ JELMERT, ${ }^{2}$ A RØNNEBERG ${ }^{3}$ \\ From the Medical Department, ${ }^{\prime}$ Alcatel-STK A/S, N-0508 Oslo 5, Department of Occupational Medicine, ${ }^{2}$ \\ Telemark Sentralsjukehus, $N$-3900 Porsgrunn, and Occupational Hygiene and Safety Department, ${ }^{3}$ Alcatel-STK \\ $A / S, N-0508$ Oslo 5, Norway
}

ABSTRACT Cytogenetic and haematological parameters were studied in 31 oil exposed workers and 31 office workers matched for age and smoking, all men employed by a Norwegian cable manufacturing company. Information was obtained about tobacco and alcohol consumption, infections, allergies, chronic diseases, use of medicines, and exposure to radiography. A decrease in the absolute lymphocyte counts was observed in the most heavily exposed subgroup $(\mathrm{p}<0.05)$ but no other significant differences were found between exposed workers and referents. The influence of non-occupational variables on the cytogenetic parameters was studied by stepwise multiple linear regression analysis. The frequency of sister chromatid exchanges appeared to be influenced by smoking history $(p<0.05)$ and season of sampling $(p<0.01)$ and, if season was excluded, by age $(p<0.05)$ and current smoking $(p<0.05)$. The number of cells with chromosomal aberrations increased with age $(p<0.05)$ and lymphocyte count $(p<0.05)$, whereas the frequency of stable rearrangements was negatively correlated with current smoking $(\mathrm{p}<0.01)$.

A statistically significant excess of cases of lung cancer was recently reported in a small cohort of oil exposed workers from a Norwegian cable manufacturing company. 'The aim of the present study was to investigate if the occurrence of cytogenetic damage in the lymphocytes of currently exposed workers in the same company might provide further evidence of a cause effect relation and identification of risk groups. A study of haematological effects was also included, since some reports suggest that oils similar to those used in cables might induce them..$^{2-6}$

At the time of the investigation, exposure to cable oils took place during the impregnation of cables with oils, electrical testing of finished cables, and cable installation in the field. Cytogenetic and haematological parameters in oil exposed workers at these three types of workplaces were compared with values obtained from individually matched referents who were not exposed to chemicals at their present workplace.

\section{Exposure}

The cable workers had been exposed to naphthenic oils of low viscosity $\left(2-6 \mathrm{~mm}^{2} / \mathrm{s}\right.$ at $\left.40^{\circ} \mathrm{C}\right)$ and high Accepted 19 December 1988 viscosity $\left(300-600 \mathrm{~mm}^{2} / \mathrm{s}\right.$ at $\left.40^{\circ} \mathrm{C}\right)$. The low viscosity oils were hydrofinished whereas most high viscosity oils were blends of hydrotreated and aromatic base oils. Oil mist and vapours were generated by evaporation from oils at ambient temperature or at 100 $120^{\circ} \mathrm{C}$. Whereas the non-volatile high viscosity oils were mainly present as oil mist, the low viscosity oils were present as oil vapours in the workroom air. Oil mist was measured by sampling on Millipore GSWP membrane filters followed by infrared spectroscopy; total low viscosity oil concentrations were measured with a total hydrocarbon analyser. These methods have been described in detail elsewhere.

The most heavily exposed group of workers was the cable splicers of the installation department who were exposed through inhalation and skin contamination to both low viscosity and high viscosity oils for two to five days a week. Most of the work was carried out in temporary, unventilated jointing sheds. Average levels of low viscosity oil vapour were 17 and $32 \mathrm{mg} / \mathrm{m}^{3}$ at two such worksites, whereas high viscosity oil mist levels of $1-4 \mathrm{mg} / \mathrm{m}^{3}$ were recorded at one site. Some cable installation was also carried out in large halls; here the average concentrations of low viscosity oil vapours were 2 and $10 \mathrm{mg} / \mathrm{m}^{3}$ on two occasions but no oil mist measurement was performed. 
In the impregnation area exposure to vapours of low viscosity oil took place continuously whereas high viscosity oil had not been used for five years at the time of the investigation. Average low viscosity oil vapour concentrations were $11 \mathrm{mg} / \mathrm{m}^{3}$, based on measurements performed on 11 days. Dermal exposure occurred for less than four hours a week.

The test splicers were exposed through inhalation and skin contamination to both low viscosity and high viscosity oils for an average of one to two days a week. Measurements performed on two occasions showed average concentrations of low viscosity oil vapours of 4 and $10 \mathrm{mg} / \mathrm{m}^{3}$ during mounting of cables for electrical testing. No measurement of high viscosity oil mist was performed, but the conditions suggest that concentrations were lower than those measured during field installation.

\section{Material and methods}

All individuals who had worked with oil impregnated cables in impregnation, testing, or installation for the last whole month before blood sampling were eligible to take part. Thirty two individuals satisfied the inclusion criteria, all men; one refused to participate. The exposed group therefore contained 31 men and the impregnation, testing, and installation subgroups were made up by ten, four, and 17 individuals, respectively.

For each exposed man one male office worker of matching age ( \pm 1 year) was selected from company pay-lists and asked by telephone if he smoked or not. This procedure was repeated until a referent was found who matched the present smoking habits of the exposed man and agreed to participate. Office workers from technical or production departments with potential chemical exposures were not eligible. The selection procedure was performed by an assistant in the medical department.

Occupational and medical information was obtained from each individual through a guided interview performed by a company physician (KS). All jobs held within or outside the company were recorded, together with information of relevant occupational exposures. The cumulative exposure period was defined as the time employed in impregnation, testing, or installation after subtraction of periods with no exposure.

Current smoking habits (cigarettes a day) and smoking history (pack-years; $50 \mathrm{~g}$ packs a week multiplied by the number of years smoked), alcohol consumption, and the use of drugs were recorded, together with radiographic exposure, time since last common cold or other infection, chronic diseases, respiratory or skin allergies, and use of prescribed medicines for more than one week during the past year.
Table 1 Description of the study groups

\begin{tabular}{|c|c|c|}
\hline & $\begin{array}{l}\text { Exposed } \\
\text { workers } \\
(n=31)\end{array}$ & $\begin{array}{l}\text { Referents } \\
(n=3 I)\end{array}$ \\
\hline \multicolumn{3}{|l|}{ Work category: } \\
\hline Testing & 4 & - \\
\hline Impregnation & 10 & - \\
\hline Splicing & 17 & - \\
\hline \multicolumn{3}{|l|}{ Cumulative exposure period (y): } \\
\hline $0-4$ & 8 & - \\
\hline $5-9$ & 15 & - \\
\hline$\geq 10$ & 8 & - \\
\hline \multicolumn{3}{|l|}{ Age distribution (y): } \\
\hline $18-30$ & 12 & 14 \\
\hline $31-50$ & 14 & 12 \\
\hline $51-67$ & 5 & 5 \\
\hline \multicolumn{3}{|l|}{ Current smoking habits (cigarettes/day): } \\
\hline 0 & 13 & 14 \\
\hline $1-15$ & 15 & 9 \\
\hline$>15$ & 3 & 8 \\
\hline \multicolumn{3}{|l|}{ Smoking history (pack-years): } \\
\hline 0 & 4 & 8 \\
\hline $1-2$ & 4 & 2 \\
\hline 3-9 & 10 & 10 \\
\hline$\geq 10$ & 13 & 11 \\
\hline \multicolumn{3}{|l|}{ Alcohol consumption (cl $40^{\circ} /$ week) } \\
\hline$<20$ & 13 & 20 \\
\hline$\geqslant 20$ & 18 & 11 \\
\hline Prescribed medicines past 12 months & 8 & 17 \\
\hline Infections past 6 months & 15 & 21 \\
\hline Chronic diseases (not allergies) & 7 & 12 \\
\hline Respiratory and/or skin allergies & 2 & 8 \\
\hline Exposure to radiography (all types) & 29 & 31 \\
\hline
\end{tabular}

Table 1 shows the characteristics of the exposed aßd $\vec{\oplus}$ the referent groups. Chronic diseases, infections, alle gies, and the use of prescribed medicines were mere common among the referent than the exposed group. This may be due to a selection of healthier men into production and installation work, but those who most@ often used the company's medical service may also have agreed more readily than others to participate as a referent.

With the exception of two exposed men, all participants had been exposed to diagnostic radiography The referents had higher current tobacco consumption per smoker whereas smoking history was more evenly® distributed between the two groups. The average 3 current alcohol consumption was higher in the $\frac{3}{3}$ exposed group. One of the exposed men had been exposed to rubber chemicals and one referent hado worked with benzene before employment with the company.

About $20 \mathrm{ml}$ of blood were collected by venepunc- $\rightarrow$ ture in heparinised vacutainers from all participants. For each matched pair, sampling was performed N within 90 minutes on the same day. For half the pairs," blood was collected during weeks 18-24 and for the remaining pairs during weeks 33-48. If one member of a matched pair suffered from an acute infection blood sampling was postponed for both until at least twoe weeks after recovery.

Sample pairs were sent by mail to the department of ${ }^{n}$ 
occupational medicine, Telemark Central Hospital, Porsgrunn, and preparation of cultures for analysis of chromosomal damage was performed within 24 hours after venepuncture. Whole blood was cultured in Hams F 10 medium with $20 \%$ fetal calf serum and $0.008 \mathrm{ml}$ phytohaemaglutinin $\mathrm{P}$ per ml medium. The leucocyte count was adjusted to $1.0 \times 10^{6}$ per $\mathrm{ml}$ medium, and the cultures were kept for 48-52 hours and scored for stable and unstable chromosome aberrations. For sister chromatid exchange scoring, the cultures were kept for 69-72 hours, the last 48 hours in the dark with bromodeoxyuridine in a concentration of $5 \mu \mathrm{g}$ per ml medium.

The cultures were harvested and stained by conventional methods. Chromosome and chromatid breaks, rings, fragments, dicentrics, exchange figures, and markers were scored in 200 cells per person. Stable chromosome rearrangements were scored in $25 \mathrm{G}$ banded cells per person and sister chromatid exchange values were scored in 30 cells per person. All scoring was performed blind.

Blood sample pairs were also despatched by car to $\mathrm{V}$ Fürst Clinical Laboratory, Oslo, and blood smear preparation and clinical chemical analyses were performed within eight hours of venepuncture. Erythrocyte and total leucocyte counts, haemoglobin concentration, packed cell volume, and differential leucocyte counts were measured by standard methods. Absolute counts of the white blood cell subpopulations were calculated from the total leucocyte count and results from differential counting of 200 cells by microscopy of blood smears.
The BMDP statistical software was used for statistical analysis of the results. ${ }^{8}$ To compare the exposed men to their referents the Wilcoxon Mann-Whitney two sample, rank sum test (two tailed) was used (BMDP-P3S). When testing for the influence of nonoccupational factors, the Kruskal-Wallis one way analysis of variance (BMDP-P3S), stepwise linear regression (BMDP-P2R), and multiple linear regression models (BMDP-P1R) were used. In this analysis age, smoking, and alcohol consumption were treated as continuous variables, whereas the health parameters were scored as 0 (absent) -1 or $0-1-2$. For all tests a result was regarded as statistically significant if $\mathrm{p}<0.05$.

\section{Results}

Table 2 shows results of the cytogenetic analyses; no statistically significant differences in the occurrence of cytogenetic damage could be detected between the groups. In seven oil exposed workers and three referents no aberrations were found, whereas dicentric chromosomes (six workers, four referents), rings (one referent), translocations or inversions (three workers, one referent), or chromatid exchange figures (two workers, five referents) were observed in 11 workers and 11 referents.

When analysed according to work category, no significant difference could be detected in the occurrence of cytogenetic damage. The test splicers, however, showed increases in the number of cells with aberrations $(p=0.06)$, and in total number of breaks

Table 2 Cytogenetic damage in cable workers and matched referents by work category and current smoking habits $($ mean $\pm S D)$

\begin{tabular}{|c|c|c|c|c|c|}
\hline & No & $\begin{array}{l}\text { No of sister } \\
\text { chromatid exchanges } \\
\text { per cell }+\end{array}$ & $\begin{array}{l}\text { No of cells } \\
\text { with aberrations } \ddagger\end{array}$ & $\begin{array}{l}\text { Total no } \\
\text { of breaks } \$\end{array}$ & $\begin{array}{l}\text { Per cent cells } \\
\text { with stable } \\
\text { rearrangementsई }\end{array}$ \\
\hline $\begin{array}{l}\text { All exposed workers } \\
\text { Referents }\end{array}$ & $\begin{array}{l}31 \\
31\end{array}$ & $\begin{array}{l}6.3 \pm 1.3 \\
6.2 \pm 1.2\end{array}$ & $\begin{array}{l}2 \cdot 3 \pm 2 \cdot 7 \\
2 \cdot 2 \pm 1 \cdot 8\end{array}$ & $\begin{array}{l}2.9 \pm 3.2 \\
3.4 \pm 2.7\end{array}$ & $\begin{array}{l}1.3 \pm 2.6 \\
0.9 \pm 1.9\end{array}$ \\
\hline $\begin{array}{l}\text { Moderate exposure: } \\
\text { Impregnation } \\
\text { Referents } \\
\text { Test splicers } \\
\text { Referents }\end{array}$ & $\begin{array}{r}10 \\
10 \\
4 \\
4\end{array}$ & $\begin{array}{l}6.3 \pm 1.5 \\
5.9 \pm 1.0 \\
7.8 \pm 1.7 \\
7.1 \pm 1.1\end{array}$ & $\begin{array}{l}2.4 \pm 1.8 \\
3 \cdot 1 \pm 2 \cdot 2 \\
6 \cdot 8 \pm 4.4 \\
2.3 \pm 1.9\end{array}$ & $\begin{array}{l}3.2 \pm 2.4 \\
3.6 \pm 2.7 \\
7 \cdot 8 \pm 5 \cdot 7 \\
2.5 \pm 1.9\end{array}$ & $\begin{array}{l}3 \cdot 1 \pm 3 \cdot 6 \\
1 \cdot 2 \pm 2 \cdot 6 \\
0 \\
1 \cdot 0 \pm 2 \cdot 0\end{array}$ \\
\hline $\begin{array}{l}\text { Heavy exposure: } \\
\text { Splicers } \\
\text { Referents }\end{array}$ & $\begin{array}{l}17 \\
17\end{array}$ & $\begin{array}{l}5.9 \pm 0.9 \\
6.1 \pm 1.2\end{array}$ & $\begin{array}{l}1.2 \pm 1.4 \\
1.9 \pm 1.3\end{array}$ & $\begin{array}{l}1.6 \pm 1.5 \\
3.5 \pm 2.9\end{array}$ & $\begin{array}{l}0.5 \pm 1.3 \\
0.7 \pm 1.5\end{array}$ \\
\hline $\begin{array}{l}\text { Men with at least } 5 \text { ye } \\
\text { Current non-smokers } \\
\text { Exposed workers }\end{array}$ & & & & & \\
\hline $\begin{array}{l}\text { Exposed workers } \\
\text { Referents }\end{array}$ & 10 & $\begin{array}{l}0.0 \pm 1.0 \\
5.9 \pm 0.9\end{array}$ & $\begin{array}{l}3.7 \pm 2.9 \\
2.7\end{array}$ & $\begin{array}{l}4.0 \pm 4.1 \\
3.4 \pm 2 \cdot 4\end{array}$ & $\begin{array}{l}3.2 \pm 3.6 \\
2.4 \pm 2.7\end{array}$ \\
\hline $\begin{array}{l}\text { Current smokers: } \\
\text { Exposed workers } \\
\text { Referents }\end{array}$ & $\begin{array}{l}13 \\
13\end{array}$ & $\begin{array}{l}6.9 \pm 1.6 \\
6.8 \pm 1.2\end{array}$ & $\begin{array}{l}2.2 \pm 1.7 \\
2.5 \pm 1.7\end{array}$ & $\begin{array}{l}2 \cdot 6 \pm 2 \cdot 0 \\
3 \cdot 5 \pm 2 \cdot 7\end{array}$ & $\begin{array}{l}0.3 \pm 1 \cdot 1 \\
0.3 \pm 1 \cdot 1\end{array}$ \\
\hline
\end{tabular}

NS, $p<0.05$ (Wilcoxon, two tailed).

tScored in 30 cells.

tScored in 200 cells.

$\S$ Scored in 25-30 G-banded cells. 
Table 3 Haematological profiles of cable workers and matched referents by work category (mean $\pm S D$ )

\begin{tabular}{|c|c|c|c|c|c|c|c|}
\hline & No & $\begin{array}{l}\text { Haemoglobin } \\
(\mathrm{g} / \mathrm{l})\end{array}$ & $\begin{array}{l}\text { Erythrocytes } \\
\left(10^{6} / \mathrm{mm}^{3}\right)\end{array}$ & $\begin{array}{l}\text { Thrombocytes } \\
\left(10^{3} / \mathrm{mm}^{3}\right)\end{array}$ & $\begin{array}{l}\text { Neutrophils } \\
\left(10^{3} / \mathrm{mm}^{3}\right) \dagger\end{array}$ & $\begin{array}{l}\text { Lymphocytes } \\
\left(10^{3} / \mathrm{mm}^{3}\right) \dagger\end{array}$ & $\begin{array}{l}\text { Monocytes } \\
\left(10^{3} / \mathrm{mm}^{3}\right) \dagger\end{array}$ \\
\hline $\begin{array}{l}\text { All exposed workers } \\
\text { Referents }\end{array}$ & $\begin{array}{l}31 \\
31\end{array}$ & $\begin{array}{l}15.6 \pm 0.8 \\
15.7 \pm 0.8\end{array}$ & $\begin{array}{l}4.95 \pm 0.36 \\
4.99 \pm 0.27\end{array}$ & $\begin{array}{l}266 \pm 51 \\
254 \pm 48\end{array}$ & $\begin{array}{l}4 \cdot 0 \pm 2 \cdot 0 \\
3 \cdot 5 \pm 1 \cdot 2\end{array}$ & $\begin{array}{l}2.1 \pm 0.6^{*} \\
2.5 \pm 0.8\end{array}$ & $\begin{array}{l}0.3 \pm 0.2 \\
0.4 \pm 0.2\end{array}$ \\
\hline $\begin{array}{l}\text { Moderate exposure: } \\
\text { Impregnation } \\
\text { Referents } \\
\text { Test splicers } \\
\text { Referents }\end{array}$ & $\begin{array}{r}10 \\
10 \\
4 \\
4\end{array}$ & $\begin{array}{l}15.8 \pm 0.4 \\
15.6 \pm 0.5 \\
15.6 \pm 0.6 \\
15.8 \pm 1.1\end{array}$ & $\begin{array}{l}5.14 \pm 0.39 \\
4.97 \pm 0.14 \\
4.99 \pm 0.14 \\
4.82 \pm 0.45\end{array}$ & $\begin{array}{l}261 \pm 50 \\
243 \pm 43 \\
268 \pm 40 \\
223 \pm 43\end{array}$ & $\begin{array}{l}4.1 \pm 1.8 \\
3.1 \pm 1.1 \\
3.3 \pm 1.4 \\
3.5 \pm 0.5\end{array}$ & $\begin{array}{l}2.2 \pm 0.4 \\
2.3 \pm 0.4 \\
2.1 \pm 0.6 \\
2.3 \pm 0.6\end{array}$ & $\begin{array}{l}0.2 \pm 0.2 \\
0.2 \pm 0.2 \\
0.6 \pm 0.3 \\
0.4 \pm 0.1\end{array}$ \\
\hline $\begin{array}{l}\text { Heavy exposure: } \\
\text { Splicers } \\
\text { Referents }\end{array}$ & $\begin{array}{l}17 \\
17\end{array}$ & $\begin{array}{l}15.5 \pm 1.0 \\
15.8 \pm 0.8\end{array}$ & $\begin{array}{l}4.84 \pm 0.32 \\
5.03 \pm 0.26\end{array}$ & $\begin{array}{l}269 \pm 53 \\
268 \pm 47\end{array}$ & $\begin{array}{l}4 \cdot 0 \pm 2 \cdot 2 \\
3 \cdot 7 \pm 1 \cdot 3\end{array}$ & $\begin{array}{l}2.0 \pm 0.6^{*} \\
2.6 \pm 0.9\end{array}$ & $\begin{array}{l}0.3 \pm 0.2 \\
0.4 \pm 0.3\end{array}$ \\
\hline
\end{tabular}

*p $<0.05$ (Wilcoxon, two tailed).

tCalculated from total leucocyte counts and differential counts of 200 cells.

$(\mathrm{p}=0.08)$ compared with their matched referents.

Table 2 also shows the occurrence of cytogenetic damage by current smoking habits in men with at least five years cumulative exposure. Although not statistically significant, an increased number of cells with aberrations and total number of breaks was observed in the exposed non-smokers compared with the nonsmoking referents. No such difference was observed between the exposed smokers and smoking referents.

Table 3 shows the results of the haematological analyses. The only statistically significant result was a reduced number of lymphocytes in the exposed men. Analysis according to work category showed that this decrease was confined to the most heavily exposed group of cable splicers. In addition, this group had lower erythrocyte counts $(p=0.06)$ and haemoglobin levels $(p=0.11)$ than their referents. None of the haematologic parameters showed any correlation with cumulative exposure period when using five years as the dividing point (not shown in table).

Table 4 shows total lymphocyte counts in smokers and non-smokers. There was a statistically significant reduction among the non-smoking cable splicers and lower counts were also observed among the smoking splicers; this difference was not statistically significant. All smokers had higher lymphocyte counts than nonsmokers.

As exposure to oil appeared to have no effect on the cytogenetic parameters, the influence of the recorded non-occupational factors was examined. The four test splicers were excluded from this analysis, since this was the only work category in which an excess of cyto- ? genetic damage had been noted (table 2). Table $5=$ shows mean values of the four types of cytogenetic $v$ damage for the studied non-occupational factors in the remaining 58 men.

Table 6 shows results from further analyses of these data by stepwise, multiple linear regression analysis (BMDP-P2R), using the 11 non-occupational factors in table 5 as independent variables. Season of blood sampling $(p=0.001)$ and smoking history $(p=0.03)$ contributed significantly to the observed values for sister chromatid exchange and accounted for $29 \% \&$ the variance. When current smoking $(p=0.06$ chronic diseases $(p=0.06)$, and lymphocyte counit $(p=0.13)$ were included in the model, $39 \%$ of the variance was accounted for, compared with $49 \%$ when all 11 variables were entered.

Age had no influence on sister chromatid exchange $\stackrel{\odot}{\varnothing}$ values in this model, but age and season were not truly $\vec{\overrightarrow{ }}$ independent variables since the spring samples included the six oldest participants and the autumn samples the 12 youngest. Results from the age group 31-50 were therefore analysed by the Wilcoxon MannWhitney rank sum test (two tailed), and no statistically significant difference was found between the 11 spring and the 14 autumn samples in this age group. If season was excluded as a variable in the multiple regression

Table 4 Lymphocyte counts of cable workers and matched referents by current smoking habits (mean $\pm S D$ )

\begin{tabular}{|c|c|c|c|c|}
\hline & \multicolumn{2}{|c|}{ Non-smokers } & \multicolumn{2}{|c|}{ Smokers } \\
\hline & No & Lymphocytes $\left(10^{3} / \mathrm{mm}^{3}\right) \dagger$ & No & Lymphocytes $\left(10^{3} / \mathrm{mm}^{3}\right) \dagger$ \\
\hline $\begin{array}{l}\text { Exposed workers } \\
\text { Referents }\end{array}$ & $\begin{array}{l}13 \\
14\end{array}$ & $\begin{array}{l}1.9 \pm 0.5 \\
2.1 \pm 0.4\end{array}$ & $\begin{array}{l}18 \\
17\end{array}$ & $\begin{array}{l}2 \cdot 2 \pm 0.5 \\
2 \cdot 7 \pm 0.9\end{array}$ \\
\hline $\begin{array}{l}\text { Splicers } \\
\text { Referents }\end{array}$ & $\mathbf{6}$ & $\begin{array}{l}1 \cdot 5 \pm 0.4^{*} \\
2 \cdot 1 \pm 0.4\end{array}$ & $\begin{array}{l}11 \\
10\end{array}$ & $\begin{array}{l}2 \cdot 2 \pm 0 \cdot 5 \\
2 \cdot 9 \pm 1 \cdot 1\end{array}$ \\
\hline \multicolumn{5}{|c|}{$\begin{array}{l}\text { *p }<0.05 \text { (Wilcoxon, two tailed). } \\
+ \text { Calculated from total leucocyte counts and differential counts of } 200 \text { cells. }\end{array}$} \\
\hline
\end{tabular}


Table 5 Cytogenetic damage in relation to non-occupational variables for all study participants after exclusion of test splicers $(n=58)($ mean $\pm S D)$

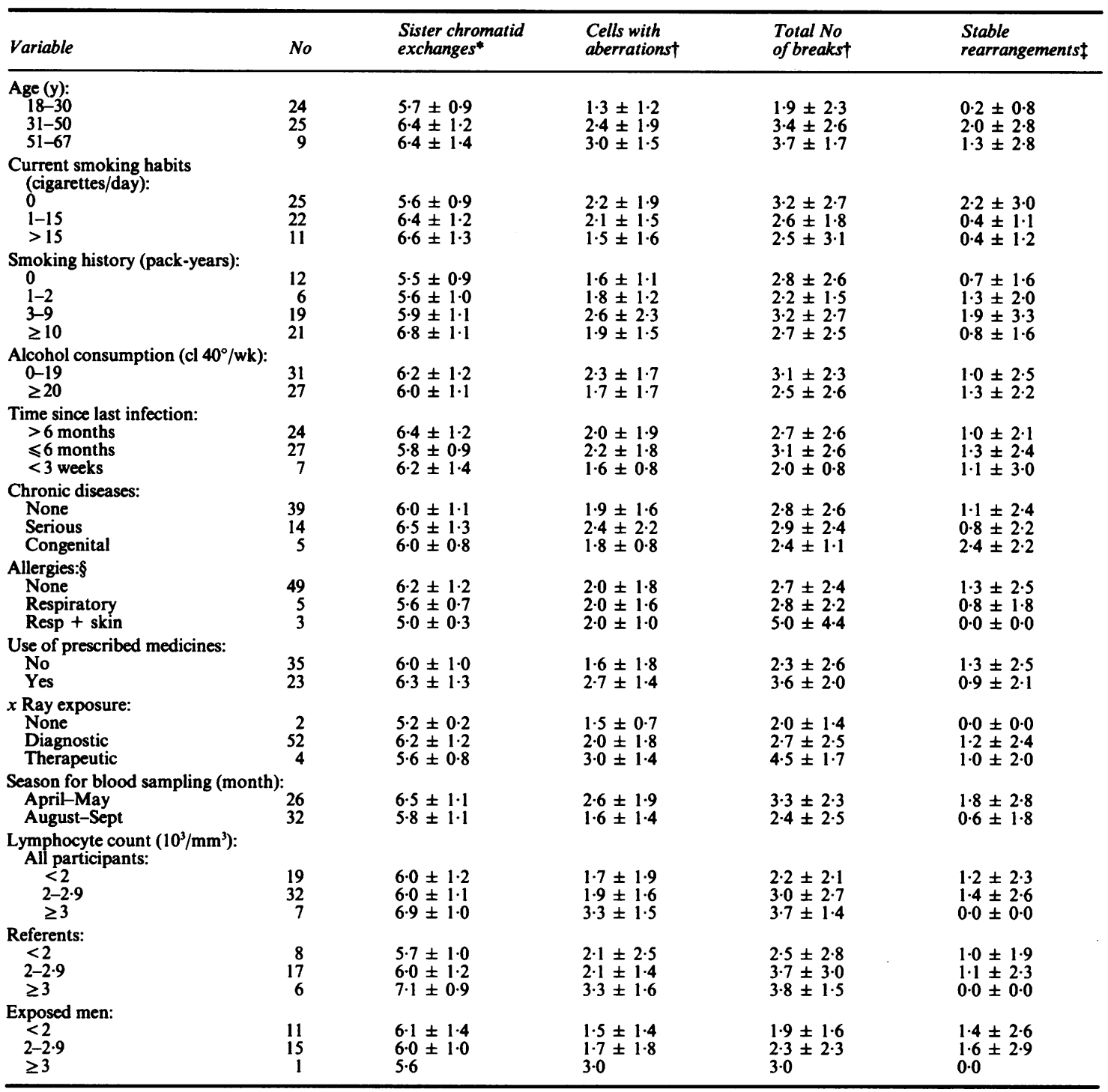

*Scored in 30 cells.

tScored in 200 cells.

tScored in 25-30 G-banded cells.

$\S$ One man with skin allergy excluded.

analysis age $(p=0.02)$ and current smoking $(p=0.001)$ were accepted as significant variables. Nevertheless, these two explained only $18 \%$ of the variance in the sister chromatid exchange value.

Age $(p=0.02)$ and lymphocyte count $(p=0.02)$ were significantly associated with the number of cells with aberrations, accounting for $22 \%$ of the variance. The inclusion of use of medicines in the model
( $p=0.07$ ) explained $26 \%$ of the variance, compared with $28 \%$ with all 11 variables entered. No statistically significant influence could be shown for any of the variables on the total number of breaks. Age, lymphocyte count, and use of medicines accounted for $17 \%$ of the variance, whereas $23 \%$ was explained with all 11 variables included. Current smoking was the only significant variable for cells with stable 
Table 6 Stepwise multiple linear regression analysis for the four cytogenetic parameters*

\begin{tabular}{|c|c|c|c|}
\hline Variables & Coefficient & $\begin{array}{l}\text { Multiple } \\
R \text {-square }\end{array}$ & $p(2$ tail $)$ \\
\hline \multicolumn{4}{|l|}{$\begin{array}{l}\text { Sister chromatid } \\
\text { exchanges: }\end{array}$} \\
\hline $\begin{array}{l}\text { Smoking history } \\
\text { + Season } \\
\text { + Current smoking } \\
\text { + Diseases } \\
\text { + No of lymphocytes } \\
\text { All variables }\end{array}$ & $\begin{array}{r}0.037 \\
-0.049 \\
0.039 \\
0.273 \\
-0.023\end{array}$ & $\begin{array}{l}0.2016 \\
0.2894 \\
0.3234 \\
0.3658 \\
0.3941 \\
0.4887\end{array}$ & $\begin{array}{l}0.032 \\
0.001 \\
0.054 \\
0.062 \\
0.125\end{array}$ \\
\hline \multicolumn{4}{|l|}{ Cells with aberrations: } \\
\hline $\begin{array}{l}\text { Age } \\
+ \text { No of lymphocytes } \\
+ \text { Use of medicines } \\
\text { All variables }\end{array}$ & $\begin{array}{l}0.037 \\
0.051 \\
0.377\end{array}$ & $\begin{array}{l}0 \cdot 1267 \\
0 \cdot 2164 \\
0 \cdot 2618 \\
0 \cdot 2844\end{array}$ & $\begin{array}{l}0.021 \\
0.020 \\
0.074\end{array}$ \\
\hline \multicolumn{4}{|l|}{ Total No of breaks: } \\
\hline $\begin{array}{l}\text { No of lymphocytes } \\
+ \text { Use of medicines } \\
+ \text { Age } \\
+x \text { Ray exposure } \\
+ \text { Allergy } \\
\text { All variables }\end{array}$ & $\begin{array}{l}0.0591 \\
0 \cdot 3838 \\
0.0396 \\
0.8403 \\
0.4755\end{array}$ & $\begin{array}{l}0.0924 \\
0.1412 \\
0.1663 \\
0.1839 \\
0.2044 \\
0.2298\end{array}$ & $\begin{array}{l}0.075 \\
0 \cdot 245 \\
0 \cdot 145 \\
0 \cdot 390 \\
0 \cdot 253\end{array}$ \\
\hline \multicolumn{4}{|c|}{ No of stable rearrangements: } \\
\hline $\begin{array}{l}\text { Current smoking } \\
\text { + Disease } \\
\text { + Allergy } \\
\text { + Age } \\
\text { + Use of medicines } \\
\text { All variables }\end{array}$ & $\begin{array}{r}-0.1243 \\
-0.5006 \\
-0.4557 \\
0.0254 \\
-0.4028\end{array}$ & $\begin{array}{l}0.1252 \\
0.1524 \\
0.1703 \\
0.1798 \\
0.2377 \\
0.2848\end{array}$ & $\begin{array}{l}0.003 \\
0 \cdot 140 \\
0 \cdot 263 \\
0 \cdot 327 \\
0 \cdot 191\end{array}$ \\
\hline
\end{tabular}

*The program (BMDP-2R) selected the independent variables which had a significant influence on the cytogenetic parameter in question and the remaining variables were included manually according to their influence as indicated by the program.

rearrangements $(p=0.003)$ but with a negative correlation coefficient.

To test the influence of age on the cytogenetic parameters further, the Kruskal-Wallis one way analysis of variance was used on the three age groups (table 5). A statistically significant increase with age was found for cells with aberrations $(p=0.01)$, total number of breaks $(p=0.01)$, and stable rearrangements $(p=0.02)$ but not for sister chromatid exchange values $(p=0 \cdot 12)$.

\section{Discussion}

A statistically significant decrease in absolute lymphocyte counts was observed in the exposed group, confined to the most heavily exposed subgroup of cable splicers (table 3). Decreased lymphocyte counts have previously been reported from two independent studies of rats after subchronic exposure to petroleum products within the same boiling range as low viscosity cable oil. ${ }^{23} \mathrm{~A}$ trend towards lower erythrocyte counts and haemoglobin levels was also seen among the cable splicers, although these results were not statistically significant. This is of interest since bone marrow injury with anaemia has been reported in men after skin exposure to kerosene. ${ }^{46}$ The clinical importance of these findings is uncertain.
No statistically significant difference in the occurrence of cytogenetic damage could be shown between the exposed workers and their referents. I particular, the most heavily exposed group of cable splicers showed lower results than their referents fo $\overrightarrow{\text { क् }}$ all cytogenetic parameters (table 2). Non-significant increases in the number of cells with aberrations ang total number of breaks were, however, noted amon the test splicers (table 2). While having experienced the least exposure to oils, this group was regularly expose\& to electric fields during cable testing. The study of such exposure was not included in the protocol of the present investigation and the number of test splicers is too small to permit any conclusion.

The detection of exposure related cytogenetis damage might have been hindered by the difference i the distribution of health variables between the exposed workers and the referents (table 1). TФ investigate this we excluded all pairs where one or both had suffered from an infection in the past six months, if chronic disease, or an allergy. Subsequently, we also' excluded all pairs in which one or both men had use 9 prescribed medicines in the past year, leaving only tent pairs for comparison. In both cases no significan difference could be detected in the occurrence of cytogenetic damage between the remaining exposed men and their referents. The negative results of the present study are thus unlikely to be due to confounding from differences in non-occupational factors. $\delta$

Negative results have been reported from experfo mental mutagenicity assays of oils similar to the cifilg oils, ${ }^{910}$ whereas increased frequencies of chromos aberrations have recently been reported in glass makers exposed to oil mist at less than $5 \mathrm{mg} / \mathrm{m}^{3}$ frorn lubricant oils subjected to process temperatures of $600-800^{\circ} \mathrm{C}$. ${ }^{11}$ Polynuclear aromatic hydrocarbon may well have been generated in the oils at such temperatures but not at the much lower temperaturesof less than $120^{\circ} \mathrm{C}$ used in cable manufacture.

In the absence of exposure related cytogenetis effects the information collected about non occupational parameters permitted a detailed analys of their influence on the types of chromosoma damage studied.

\section{SMOKING AND ALCOHOL CONSUMPTION}

The present study confirms earlier observations of the effect of current smoking habits and smoking histores on sister chromatid exchange. ${ }^{12-14}$ The smoking. referents appeared to smoke more than the smoking cable workers (table 1) and one might speculate that this could have influenced results for sister chromatiof exchanges in these two groups. No more sistero chromatid changes were observed among the nop smoking cable workers than among the non-smoking referents (table 2). The effect of smoking 
chromosomal aberrations is much more disputed, ${ }^{15-17}$ and the present study does not confirm the increase in aberrations with smoking reported from an earlier investigation. ${ }^{18}$ No association could be detected between the studied types of cytogenetic damage and alcohol consumption.

\section{SEASON}

As in previous studies the time of year for blood sampling was found to be a significant variable for sister chromatid exchange values, spring samples showing higher values than samples taken in the late summer. ${ }^{15} 16$ Season and smoking history accounted for $29 \%$ of the variance, but interpretation is made difficult by the fact that spring samples were taken from older subjects. When season was excluded from the model, age and current smoking became the significant variables. These accounted for only $18 \%$ of the variance, however, suggesting that some of the increase in sister chromatid exchange values may be due to seasonal variation.

\section{AGE}

Conflicting results have been reported from previous studies of the influence of age on the occurrence of cytogenetic damage. ${ }^{151719-22}$ We found statistically significant increases in aberrations, breaks, and stable rearrangements with increasing age, using the Kruskal-Wallis ranking test. When using multiple regression analysis, a significant association with age was shown for cells with aberrations, and for sister chromatid exchanges if season was excluded from the model.

\section{LYMPHOCYTE COUNT}

Lymphocyte count was the most important explanatory variable for aberrations and breaks in the multiple regression analysis, although all cultures were adjusted to the same cell concentration. A trend towards increased cytogenetic damage with increasing lymphocyte counts was observed both among the referents and the cable workers (test splicers excluded) when tested separately (table 5).

Exposure appeared to be associated with decreased lymphocyte counts and may have affected the various lymphocyte subpopulations differently. The results also confirmed previous findings that non-smokers have lower lymphocyte counts than smokers. ${ }^{23}$ Differences in differential lymphocyte counts may influence the observed values for cytogenetic damage but studies by more sophisticated methods are clearly needed to elucidate this.

\section{HEALTH VARIABLES}

There was no significant association between any of the cytogenetic damage parameters and the variables $x$ ray exposure, medicine use, infections, chronic diseases, or allergies. The total number of breaks, however, was somewhat higher among those few men with allergies or high $x$ ray exposure (table 5) and use of medicines was found to be one of the three most important explanatory variables for breaks in the linear regression tests (table 6).

The results from the analysis of the non-occupational variables underline the importance of matching for smoking, age, and the time of blood sampling. It also seems to be important to recruit the reference group from a population with similar social and occupational status as the exposed group to minimise confounding from health variables.

We thank Vera Haugan and Kjell O Clausen for cytogenetic help, Hjørdis Sødem for selecting referents and blood sampling, and Per C Hagen of Telemark College, Bø, for statistical advice.

\section{References}

1 Rønneberg A, Andersen A, Skyberg K. Mortality and incidence of cancer among oil exposed workers in a Norwegian cable manufacturing company. Part II: Mortality and cancer incidence 1953-84. Br J Ind Med 1988;45:595-601.

2 Nau CA, Neal J, Thornton M. $C_{9}-C_{12}$ Fractions obtained from petroleum distillates. An evaluation of their potential toxicity. Arch Environ Health 1966;12:382-93.

3 Rao GS, Kannan K, Goel SK, Pandya KP, Shanker R. Subcutaneous kerosene toxicity in albino rats. Environ Res 1984;35:516-30.

4 Cavanaugh JR, Wilner PR. Aplastic anemia due to kerosine. Medical Annals of the District of Columbia 1939;8:140-4.

5 Hiebel J, Gant HL, Schwartz SO, Friedmann IA. Bone marrow depression following exposure to kerosine. A report of three cases. Am J Med Sci 1963;246:91-7.

6 Johnson DE. Hypoplastic anemia following chronic exposure to kerosene. J Am Med Wom Assoc 1955;10:421-4.

7 Rønneberg A, Skyberg K. Mortality and incidence of cancer among oil exposed workers in a Norwegian cable manufacturing company. Part I: Exposure conditions 1920-79. Br J Ind Med 1988;45:589-94.

8 Dixon WJ, ed. BMDP statistical software. Los Angeles: University of California Press, 1985.

9 Conaway CC, Schreiner CA, Cragg ST. Mutagenicity evaluation of petroleum hydrocarbons. In: MacFarland HN, Holdsworth CE, MacGregor JA, Call RW, Kane ML, eds. The toxicology of petroleum hydrocarbons. Washington: American Petroleum Institute, 1982:128-38.

10 MacGregor JA, Conaway CC, Cragg ST. Predictivity of the Salmonella/microsome assay for carcinogenic and noncarcinogenic complex petroleum hydrocarbon mixtures. In: MacFarland HN, Holdsworth CE, MacGregor JA, Call RW, Kane ML, eds. The toxicology of petroleum hydrocarbons. Washington: American Petroleum Institute. 1982:149-61.

11 Srám RJ, Holá N, Kotesovec F, Novákova A. Cytogenetic analysis of peripheral blood lymphocytes in glass workers occupationally exposed to mineral oils. Mutat Res 1985; 144:277-80.

12 Husgafvel-Pursiainen $K$, Sorsa $M$, Järventaus $H$, Norppa $H$. Sister chromatid exchanges in lymphocytes of smokers in an 
experimental study. Mutat Res 1984;138:197-203.

13 Lambert B, Lindblad A, Nordenskjøld M, Werelius B. Increased frequency of sister chromatid exchanges in cigarette smokers. Hereditas 1978;88:147-9.

14 Soper KA, Stolley PD, Galloway SM, Smith JG, Nichols WW, Wolman SR. Sister chromatid exchange (SCE) report on control subjects in a study of occupationally exposed workers. Mutat Res 1984;129:77-88.

15 Sinha AK, Linscombe VA, Gollapudi BB, Jersy GC, Flake RE. Cytogenetic variability of lymphocytes from phenotypically normal men: influence of age, smoking, season and sample storage. J Toxicol Environ Health 1986;17:327-45.

16 Zhou X, Li L, Cui M, Yu R, Li L, Yan Z. Cytogenetic monitoring of petrochemical workers. Mutat Res 1986;175:237-42.

17 Galloway SM, Berry PK, Nichols WW, et al. Chromosome aberrations in individuals occupationally exposed to ethylene oxide, and in a large control population. Mutat Res 1986;170:55-74.

18 Hansteen IL, Jelmert $\varnothing$, Torgrimsen T, Försund B. Low human exposure to styrene in relation to chromosome breaks, gaps an $\overline{\bar{g}}$ sister chromatid exchanges. Hereditas 1984;100:87-91.

19 Funes-Cravioto F, Zapata-Gayon C, Kolmodin-Hedman B, et a Chromosome aberrations and sister chromatid exchange in workers in chemical laboratories and a rotaprinting factory and. in children of woman laboratory workers. Lancet 1977; i 322-5.

20 Sarto F, Cominato I, Pinton AM, et al. Cytogenetic damage io workers exposed to ethylene oxide. Mutat Res 1984;138:185-9포․

21 Evans HJ, Buckton KE, Hamilton GE, Carothers A. Radiation induced chromosome aberrations in nuclear dockyard workers Nature 1979;277:531-4.

22 Steenland K, Carrano A, Ratcliffe J, Clapp D, Ashworth L Meinhardt T. A cytogenetic study of papaya workers exposed to ethylene dibromide. Mutat Res 1986;170:151-60.

23 Van Sittert NJ, De Jong G, Clare MG, et al. Cytogenetic immunological, and haematological effects in workers in an ethylene oxide manufacturing plant. Br J Ind Med 1985;42 19-26.

\section{Correspondence and editorials}

The British Journal of Industrial Medicine welcomes correspondence relating to any of the material appearing in the journal. Results from preliminary or small scale studies may also be published in the correspondence column if this seems appropriate. Letters should be not more than 500 words in length and contain a minimum of references. Tables and figures should be kept to an absolute minimum. Letters are accepted on the understanding that they may be subject to editorial revision and shortening.

The journal now also publishes editorials which are normally specially commissioned. The Editor welcomes suggestions regarding suitable topics; those wishing to submit an editorial, however, should do so only after discussion with the Editor. 